\title{
Campylobacter jejuni infection and virulence- associated genes in children with moderate to severe diarrhoea admitted to emergency rooms in northeastern Brazil
}

Correspondence Josiane da S. Quetz jquetz@gmail.com

Received 11 November 2011 Accepted 8 December 2011
Josiane da S. Quetz, ${ }^{1}$ Ila F. N. Lima, ${ }^{1}$ Alexandre Havt, ${ }^{1}$ Mara M. G. Prata, ${ }^{1}$ Paloma A. Cavalcante, ${ }^{1}$ Pedro H. O. S. Medeiros, ${ }^{1}$ David A. C. Cid, ${ }^{1}$ Milena L. Moraes, ${ }^{1}$ Luís Carlos Rey, ${ }^{1}$ Alberto M. Soares, ${ }^{1}$ Rosa M. S. Mota, ${ }^{2}$ Bernhard H. Weigl, ${ }^{3}$ Richard L. Guerrant ${ }^{4}$ and Aldo A. M. Lima ${ }^{1}$

\author{
${ }^{1}$ Institute of Biomedicine for Brazilian Semi-Arid/Clinical Research Unit, \\ Federal University of Ceara, Fortaleza, CE 60430-270, Brazil \\ ${ }^{2}$ Science Center/Unit of Statistics, Federal University of Ceara, Fortaleza, CE 60455-760, Brazil \\ ${ }^{3}$ Program for Appropriate Technology in Health (PATH), Seattle, Washington, WA 98107, USA \\ ${ }^{4}$ Center for Global Health, University of Virginia, Charlottesville, VA 22908, USA
}

\begin{abstract}
Campylobacter is an important cause of foodborne gastroenteritis. We determined the occurrence of Campylobacter jejuni and Campylobacter coli, using culture-based methods and PCRs targeting virulence-associated genes (VAGs) among children aged $\leqslant 14$ years who were treated for diarrhoea at emergency rooms in northeastern Brazil. Genomic DNA was extracted directly from stool samples collected from 366 children. A questionnaire was also applied to qualify the clinical conditions presented by each child at the time of admission. C. jejuni and C. coli were detected in $16.4 \%(60 / 366)$ and $1.4 \%$ (5/366) of the diarrhoeal samples, respectively, by PCR, a much higher proportion than that detected by conventional methods. C. jejuni VAGs were detected in the following proportions of hipO-positive samples: ciaB, $95 \%$ (57/60); dnaJ, 86.7\% (52/60); racR, 98.3\% (59/60); flaA, $80 \%$ (48/60); pldA, $45 \%$ (27/60); cdtABC, $95 \%$ (57/60); and pVir $0 \%$ (0/ 60). Particular symptoms, such as blood in faeces, vomiting, fever, and/or abdominal pain, were not associated with detection of $C$. jejuni nor were they associated with any particular VAG or combination of VAGs $(P>0.05)$. C. jejuni and its VAGs were detected in a substantial proportion of the children admitted. Further efforts shall be directed towards elucidating whether these genetic factors or their expressed proteins play a role in Campylobacter pathogenesis.
\end{abstract}

\section{INTRODUCTION}

The genus Campylobacter, a group of thermotolerant, microaerophilic, Gram-negative bacteria, includes a number of pathogens that primarily cause gastrointestinal disease in humans, particularly Campylobacter jejuni and Campylobacter coli. Campylobacter-associated gastroenteritis is thought to occur through zoonotic transmission, being acquired from exposure to tainted food and/or contaminated drinking water (Sherman et al., 2010). Campylobacter infection frequently presents as self-limiting acute enteritis with diarrhoea, malaise, fever and abdominal pain, sometimes with vomiting and the presence of blood in faeces

Abbreviations: CDT, cytolethal distending toxin; MicD, microbiological diagnosis; VAGs virulence-associated genes.
(Allos, 2001); disruption of epithelial cells and inflammation of the intestinal mucosa are hallmark features of severe cases (Beltinger et al., 2008). C. jejuni and C. coli cause significant morbidity worldwide, especially in children (Amieva, 2005; Tam et al., 2003; Wang et al., 2008; Fernández et al., 2008).

Adherence and colonization are crucial steps in the pathogenesis of $C$. jejuni. Flagella have a major role in invasion; markedly reduced internalization in vitro has been reported with flaA ${ }^{-}$C. jejuni mutants (Wassenaar, 1997). The genes racR and dnaJ are determinants for C. jejuni colonization and are presumably expressed in response to conditions encountered in the intestinal microenviroment, such as differences in temperature between environmental reservoirs and human intestines (Konkel et al., 1998; Brás et al., 1999). The ciaB gene encodes Campylobacter invasion 
antigen B protein, which confers invasive properties, as shown by $C$. jejuni ciaB null mutants which display a significant reduction in internalization (Konkel et al., 1999). Also, $\mathrm{CiaB}$ and other secreted proteins require functional flagella export apparatus for their secretion (Konkel et al., 2004; Dasti et al., 2010). The pldA gene encodes a protein involved in the synthesis of an outer membrane phospholipase that has also been related to cellular invasion (Ziprin et al., 2001). The plasmid pVir is associated with the ability of $C$. jejuni to adhere to and invade cells in vitro and has been shown to increase virulence in vivo (Bacon et al., 2000). Tracz et al., 2005 showed that in very invasive infections, with a dysenteric phenotype, pVir could be detected. Last but not least, cytolethal distending toxin (CDT), a very efficient bacterial toxin, causes cell distension and death due to blocking of cell division. This toxin is produced by a variety of Gram-negative bacteria including Campylobacter species, Shigella species, Escherichia coli and Haemophilus ducreyi (Young \& Schauer, 2000; Yamasaki et al., 2006). The CdtA and CdtC subunits appear to be responsible for binding to the membrane receptors of susceptible cells, while the CdtB subunit is responsible for the toxic effect at the nucleus level, causing dsDNA cleavage as a result of its DNase I (EC 3.1.21.1) activity (Lara-Tejero \& Galán, 2001).

Previous data from our group, obtained from a casecontrol study of diarrhoea acquired in the community, demonstrated the presence of $C$. jejuni and C. coli. The prevalence rates for $C$. jejuni reached $9.6 \%$ for the diarrhoea group and $7.2 \%$ for the non-diarrhoea group (da Silva Quetz et al., 2010). These data prompted us to assess the detection rate of Campylobacter in children from the same geographical area with community-acquired diarrhoea who were treated in local hospitals. Thus, in the present work we focused our efforts on describing the importance of $C$. jejuni as an enteropathogen among children who were treated for diarrhoea at emergency rooms in Fortaleza, Ceara, an impoverished area in Brazil. We also characterized C. jejuni virulence-associated genes (VAGs) that may play a role in $C$. jejuni pathogenicity. We performed these analyses on DNA extracted directly from faecal material. Moreover, we examined the data for correlations between selected clinical parameters and the molecular profile of each sample.

\section{METHODS}

Ethical clearance, study site and population. This study was part of a project entitled 'Diarrhea Enteric Card (DEC)' aiming to develop a point-of-care microfluidic PCR-based multiplex assay for four common bacterial enteric pathogens (Yager et al., 2006; Weigl et al., 2006). The project was approved by the local and national ethical committees in Brazil (HIAS 80/06 and CONEPE 13523/2007, respectively). A consent form was read and signed by the guardians of each child whom received medical care due to a diarrhoeal event, after being admitted to emergency rooms of two paediatric hospitals in Fortaleza, Ceará, Brasil: the Albert Sabin Children Hospital (Hospital Infantil Albert Sabin, HIAS) and the Center for Child Assistance Lúcia de Fátima R.G. Sá (CAC). A questionnaire was used to qualify the clinical symptoms presented by each child at the time of admission, for example, presence of blood in stools, vomiting, fever, and abdominal pain. Exclusion criteria included antibiotic treatment or breastfeeding prior to admission.

Stool sample collection and microbiological tests. From May 2008 to April 2009, stool samples were collected from 366 children (014 years of age) with diarrhoea, who were treated in emergency rooms in Fortaleza, Ceara, Brazil (HIAS and CROA). Fresh stool specimens (one per subject) were obtained in collection cups and all specimens were processed within $4 \mathrm{~h}$ of collection. The stool specimens were tested for the presence of Campylobacter, diarrhoeagenic E. coli, Salmonella and Shigella, following standard microbiological procedures. The remaining faecal material was aliquoted and stored at $-80{ }^{\circ} \mathrm{C}$ until required for DNA extraction directly from faecal samples.

Phenotypic identification of Campylobacter species was performed by analysing colony morphology and growth characteristics. Campylobacter species typically produce non-haemolytic, translucent, watery colonies, some producing discrete, colourless colonies, and cells typically present cytochrome oxidase (EC 1.9.3.1) activity and appear as Gram-negative 'gull's wings'-shaped bacilli under light microscopy using Gram stain. The microbiological diagnosis (MicD) was designated as being 'suggestive' or 'not suggestive' of Campylobacter.

Genomic DNA. Genomic DNA was extracted from 366 stool samples using a QIAamp DNA stool Mini kit (Qiagen). The purity of DNA extracted was determined by measuring $A_{260} / A_{280}$. In order to certify the quality of our extraction procedures, we performed an internal control PCR for all DNA extracted directly from faecal aliquots just before the PCR diagnosis procedures. This internal control PCR amplified the rrs (16S rRNA) gene (Wang et al., 2002; Brandal et al., 2007). Positive control DNA was extracted from C. jejuni ATCC 33291 and C. coli INCQS 00263 (kindly provided by Oswaldo Cruz Foundation, Rio de Janeiro, Brazil).

Oligonucleotides, PCR and multiplex-PCR amplifications. PCR primers for detection of $C$. jejuni and C. coli, as well as the $c d t A B C$ operon, were used as previously described (da Silva Quetz et al., 2010). Primers used for detection of VAGs in C. jejuni and the rrs internal control PCR along with the optimal cycling conditions are listed in Table 1. All primers were synthesized by Invitrogen.

Two sets of PCRs or multiplex-PCRs were performed in duplicate and the results were coincident. PCRs contained $12.5 \mu \mathrm{l}$ GoTaq Green Master Mix $2 \times$ (Promega); $200 \mathrm{nM}$ each forward and reverse primers and $2.5 \mu \mathrm{l}$ template DNA, made up to a final volume of $25 \mu \mathrm{l}$ with nuclease-free water (Promega). Multiplex-PCRs contained $15 \mu \mathrm{l}$ Qiagen Multiplex Master Mix Solution $2 \times$ and Q-solution enhancer (Qiagen); $200 \mathrm{nM}$ each forward and reverse primers and $2.5 \mu \mathrm{l}$ template DNA, made up to a final volume of $25 \mu \mathrm{l}$ with nuclease-free water. Each reaction product was run on a $3 \%$ agarose gel in Tris/ acetate-EDTA buffer. Gels were stained with ethidium bromide and photographed using a ChemiDoc XRS UV transilluminator (Bio-Rad).

ELISA for detection of Campylobacter antigen. In order to provide more support to the molecular assay, we performed a Campylobacter ProSpecT Microplate Assay (Remel) on 74 samples, following the manufacturer's guidelines. The plates were read spectrophotometrically at $450 / 620 \mathrm{~nm}$ using an ELISA Microplate Reader (Bio-Rad) and the results were interpreted according to the manufacturer's instructions. The analysis was done in order to assess the degree of concordance between the results of PCR and ELISA.

Statistical analysis. Data were entered twice by two independent persons, validated using Excel software (Microsoft) and analysed using SPSS version 13.0. The analysis of associations was performed in contingency tables, using Fisher's exact test. To compare means, 
Table 1. PCR primers, amplification conditions, and expected PCR products for C. jejuni VAGs

For all PCR conditions, an initial denaturation step (5 min for single PCR and 15 min for multiplex PCR at $95{ }^{\circ} \mathrm{C}$ ) and a final extension step (10 min at $72{ }^{\circ} \mathrm{C}$ ) were performed in a MyCycler thermocycler (Bio-Rad). F, Foward; R, reverse.

\begin{tabular}{|c|c|c|c|c|c|}
\hline Target gene & Primer sequence $\left(5^{\prime} \rightarrow 3^{\prime}\right)$ & $\begin{array}{c}\text { GenBank } \\
\text { accession no. }\end{array}$ & $\begin{array}{l}\text { Amplicon } \\
\text { size (bp) }\end{array}$ & $\begin{array}{l}\text { PCR conditions } \\
\text { ( } 35 \text { cycles })\end{array}$ & Reference(s) \\
\hline $\begin{array}{l}\text { Internal control } \\
r r s^{\star} \dagger \\
\text { E. coli } 16 \mathrm{SrRNA}\end{array}$ & F: CCCCCTGGACGAAGACTGAC & JN547259.1 & 401 & $\begin{array}{l}20 \mathrm{sec} \text { at } 95{ }^{\circ} \mathrm{C} \text {, } \\
20 \mathrm{sec} \text { at } 63{ }^{\circ} \mathrm{C} \text {, } \\
45 \mathrm{sec} \text { at } 72{ }^{\circ} \mathrm{C}\end{array}$ & $\begin{array}{l}\text { Wang et al. (2002), } \\
\text { Brandal et al. } \\
\text { (2007) }\end{array}$ \\
\hline & R: ACCGCTGGCAACAAAGGATA & & & & \\
\hline $\begin{array}{l}\text { C. jejuni VAGs } \\
\text { ciaBs } \ddagger \\
\text { Campylobacter } \\
\text { invasion antigen B }\end{array}$ & F: TCATGCGGTGGCATTAGAATGGG & AF114831.1 & 658 & $\begin{array}{l}30 \mathrm{sec} \text { at } 95^{\circ} \mathrm{C} \text {, } \\
30 \mathrm{sec} \text { at } 64{ }^{\circ} \mathrm{C} \text {, } \\
45 \mathrm{sec} \text { at } 72{ }^{\circ} \mathrm{C}\end{array}$ & Konkel et al. (1999) \\
\hline $\begin{array}{l}d n a J^{\star} \ddagger \\
\text { chaperone protein } \\
\text { DnaJ }\end{array}$ & $\begin{array}{l}\text { R: AGGTCTAACTTCATCAACCCTTTGCCA } \\
\text { F: AGGCTTTGGCTCATCACGTCG }\end{array}$ & AF053962.1 & 574 & & Konkel et al. (1998) \\
\hline $\begin{array}{l}\operatorname{racR}^{\star} \ddagger \\
\text { DNA-binding } \\
\text { response regulator }\end{array}$ & $\begin{array}{l}\text { R: GGTCGCTTCACCGCGTATGG } \\
\text { F: TGGGGCTTCAAATCGGTGCTGA }\end{array}$ & GQ491062.1 & 326 & & $\begin{array}{l}\text { Hamidian et al. } \\
\qquad(2011)\end{array}$ \\
\hline $\begin{array}{l}\text { fla } A^{*} \ddagger \\
\text { flagellin }\end{array}$ & $\begin{array}{l}\text { R: GCGACCGATGATAACATCAAGGCT } \\
\text { F: AGCTGCTTCGCAACTTTCTACGGT }\end{array}$ & AF369585.1 & 325 & $\begin{array}{l}30 \mathrm{sec} \text { at } 95^{\circ} \mathrm{C} \text {, } \\
30 \mathrm{sec} \text { at } 59^{\circ} \mathrm{C} \text {, } \\
45 \mathrm{sec} \text { at } 72{ }^{\circ} \mathrm{C}\end{array}$ & $\begin{array}{l}\text { Fitzgerald et al. } \\
\qquad(2001)\end{array}$ \\
\hline $\begin{array}{l}\text { pld } A^{\star} \ddagger \\
\text { phospholipase A }\end{array}$ & $\begin{array}{l}\text { R: TGCACTCTCGGCTGCAAAGTCT } \\
\text { F: AAGAGTGAGGCGAAATTCCA } \\
\text { R: GCAAGATGGCAGGATTATCA }\end{array}$ & СР000025.1 & 385 & & Fouts et al. (2005) \\
\hline $\begin{array}{l}\mathrm{pVir} \dagger \\
\text { virulence plasmid }\end{array}$ & F: GAACAGGAAGTGGAAAAACTAGC & AF226280.2 & 708 & $\begin{array}{l}30 \mathrm{sec} \text { at } 95^{\circ} \mathrm{C} \text {, } \\
30 \mathrm{sec} \text { at } 55^{\circ} \mathrm{C} \text {, } \\
1 \mathrm{~min} \text { at } 72{ }^{\circ} \mathrm{C}\end{array}$ & Bacon et al. (2002) \\
\hline
\end{tabular}

${ }^{\star}$ Chromosomal gene.

$\dagger$ Single PCR.

\$Multiplex PCR.

the normality of the data distribution was first checked. When normal distribution of the data was confirmed, the comparison of the two means was performed using Student's $t$-test; an ANOVA test was used to compare three or more means. Sub-hypotheses were analysed by using the Bonferroni test. When normality was not accepted, the comparison of two means was performed by using the MannWhitney test. The significance level was set at $P<0.05$. The Kappa index was used to determine the degree of concordance between the results of PCR and ELISA tests.

\section{RESULTS AND DISCUSSION}

\section{Population description}

The details of the population studied, including age, gender and family income are summarized in Table 2 . The majority of children treated were 2 years old or younger $(214 / 366$, $58.5 \%$ ), which is consistent with the age considered most susceptible to diarrhoeal diseases worldwide (Podewils et al., 2004; Vu Nguyen et al., 2006). The group treated were considered to be similar with respect to their age $(P=0.787$, Student's $t$-test). The female/male ratio was 0.58 , with boys accounting for the majority of the patients $(P=0.024)$. Approximately $75 \%$ of all the children admitted lived in homes where the monthly income was less than US\$ 250. Nearly $90 \%$ of the patients' households had piped water. About 9.5\% (35/366) of the patients' mothers were illiterate or had less than 3 years of schooling, $47.8 \%(175 / 366)$ had between 4 and 11 years of schooling, and $24.0 \%(88 / 366)$ had more than 12 years of schooling.

\section{Assessment of clinical parameters}

The diarrhoeal illnesses of the children enrolled in this hospital-based study were moderate to severe based on the 
Table 2. Details of the studied population and parental socioeconomic information from 366 children treated for diarrhoea at emergency rooms in Fortaleza, Brazil, during the period May 2008-April 2009

\begin{tabular}{|lrrr|}
\hline Characteristic & No. $(\%)$ & Median & Range \\
\hline Male patients & $212(57.9)$ & & \\
Age (years) & & & \\
$\quad \leqslant 2$ & $214(58.5)$ & 0.85 & \\
$2-5$ & $86(23.5)$ & 2.85 & \\
$\geqslant 5$ & $66(18.0)$ & 7.57 & \\
Total & $366(100)$ & 1.52 & $0.02-13.92$ \\
Monthly income (US\$ $\left.{ }^{*}\right)$ & & & \\
$<200$ & $77(21.9)$ & 125.00 & \\
$200-250$ & $188(53.4)$ & 207.50 & \\
$>250$ & $87(24.7)$ & 400.00 & \\
Total & $352(96.1)$ & 207.50 & $0-1500$ \\
& & & \\
\hline
\end{tabular}

${ }^{\star} 1$ US $\$=2$ Real - mean exchange rate of during the time of study.

symptoms reported and considering the fact that the guardians took their child to the appropriate health personnel for immediate attention.

According to the parental responses to the questionnaires, $>95 \%$ of the children were experiencing acute diarrhoea less than 13 days prior to date of attendance, as opposed to the $3.1 \%$ with persistent diarrhoea, experiencing diarrhoea for 14-30 days prior to date of attendance. Other data regarding clinical parameters are as follows: $22.6 \%$ (83/ 366) of children presented blood in the stool, $72.9 \%$ (267/ 366) presented abdominal pain and vomiting, and fever was reported in $74.6 \%(273 / 366)$ of cases.

\section{Microbiological detection vs molecular detection}

Using traditional diagnostic techniques, a bacterial pathogen was detected in $30.3 \%(111 / 366)$ of the stool samples examined. Campylobacter species were found in $6.0 \%(22 /$ 366) of cases. The overall distribution of pathogens found is summarized in Table 3. Although there is a paucity of population-based data about Campylobacter infections in Brazil, previous case-control studies have reported that the prevalence of Campylobacter in stool samples from diarrhoeic children is between $1.7 \%$ (Moreno et al., 2010) and $11.2 \%$ (Mendes et al., 1987). The prevalence found with our culture-based methods $(6.0 \%)$ is consistent with these findings.

After the internal control for DNA extraction was confirmed as positive (Fig. 1a), the PCR assays for Campylobacter diagnosis were performed. C. jejuni and $C$. coli were detected in $16.4 \%(60 / 366)$ and $1.4 \%(5 / 366)$ of DNA samples, respectively (Table 4). Our PCR-based methods detected a higher rate of Campylobacter infections, with overall infection rate of $17.8 \%$. Assuming a prevalence of $6.0 \%$ of Campylobacter infection in Brazilian sites, the specificity, positive and negative predictive values
Table 3. Bacterial enteropathogens identified by traditional microbiological diagnostic techniques in the 366 stool specimens.

\begin{tabular}{|lc|}
\hline Micro-organism & $\begin{array}{c}\text { No. positive samples } \\
(\%)\end{array}$ \\
\hline Campylobacter spp. & $22(6.0)$ \\
E. coli non-O157:H7 & $21(5.7)$ \\
Salmonella spp. & $8(2.2)$ \\
Shigella spp. & $60(16.4)$ \\
No enteric pathogen detected & $255(69.7)$ \\
\hline
\end{tabular}

(PPV, NPV) and sensitivity were, 90.1, 34.6, 98.7 and $81.8 \%$, respectively. The sensitivity of our PCR protocol, however, must still be confirmed through further experiments using spiked stool samples.

Previous studies have shown improvements in the rate of detection of Campylobacter. These studies suggest that culture-based methods underestimate the prevalence of Campylobacter infection and that PCR-based methods are more efficient for detection of Campylobacter from faecal samples declared negative by culture-based methods (Maher et al., 2003; Singh et al., 2011). Using molecular approaches, Inglis et al. (2011) revealed that $12.2 \%$ and $4.3 \%$ of $C$. jejuni and C. coli infections, respectively, have been missed by culture-based methods of identification. In India, Sinha et al. (2004) reported that the rate of Campylobacter detection using molecular tools reached $19 \%$, as opposed to the detection rate of $4.8 \%$ using stool culture, in their study evaluating $C$. jejuni infections preceding Guillain-Barré syndrome (Sinha et al., 2004).

The increased detection rate seen with PCR-based methods in the present study is comparable to several other studies worldwide, the findings of which have demonstrated rates of Campylobacter infection in cases of childhood diarrhoea ranging from $7 \%$ in Tehran and Pakistan (Jafari et al., 2009; Soofi et al., 2011) to $30.8 \%$ in Canada (Kaboré et al., 2010), even reaching $52 \%$ in children $<4$ years old in Bulgaria (Ivanova et al., 2010). In South America, the prevalence of Campylobacter isolation in children with diarrhoea varied between $2.3 \%$ and $23.0 \%$ according to Fernández (2011).

\section{Information from ELISA tests}

From the 22 faecal samples identified by culture methods as suggestive of Campylobacter infection $\left(\mathrm{MicD}^{+}\right)$, four were PCR-negative for C. jejuni and C. coli. Therefore, an ELISA test (ELISA ProSpecT Campylobacter Assay) was performed for all $\mathrm{MicD}^{+}$samples, which revealed that $100 \%$ of these samples (22/22) had ELISA-positive results. We attribute the failure of PCR detection to the very watery characteristic of these four samples, a factor that may negatively influence the DNA extraction process. We also performed the ELISA test on an additional 52 samples, 


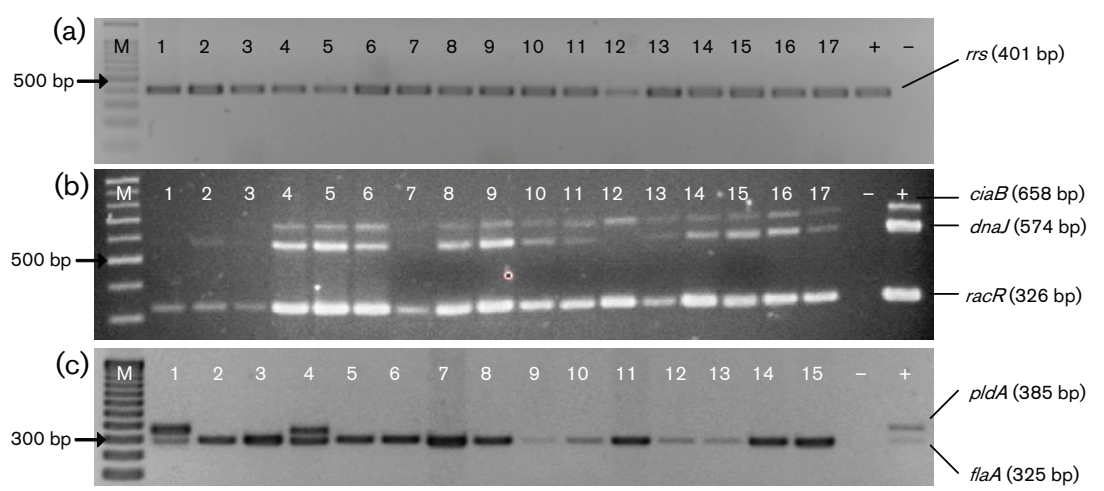

Fig. 1. Amplified products from PCR and multiplex PCR reactions targeting $C$. jejuni VAGs ciaB, dnaJ and racR (b) and $p / d A$ and fla $A$ (c) using the rrs gene (a) as an internal control. Reactions were performed using DNA samples from children with diarrhoea who were admitted to emergency rooms in Fortaleza, Brazil. Numbered columns represent amplified products from DNA samples. +, Positive control - commensal E. coli strain HS (a), C. jejuni ATCC 33291 (b, c); -, negative control (autoclaved Millia water used as template). M, 100 bp molecular marker.

chosen at random, according to the availability of $300 \mathrm{mg}$ faecal material. Based on the results obtained, we were able to demonstrate a concordance between the PCR protocol and the ELISA test, which was regular (Kappa $=0.411 \pm$ 0.112). A previous study determined that the ProSpecT Campylobacter assay presents $89.1 \%$ sensitivity and $97.7 \%$ specificity for both C. jejuni and C. coli (Dediste et al., 2003). If it had been possible to apply the ELISA to all our samples, it would have improved the concordance between our proposed molecular protocol and this immunoassay.

\section{C. jejuni virulence-associated genes}

C. jejuni VAGs have, to our knowledge, not been examined previously in Brazil. C. jejuni ( hipO)-positive samples were further tested using PCR or multiplex PCR in order to evaluate the prevalence of VAGs, the results of which are summarized in Table 4 and Fig. 1(b, c).

A combination of six VAGs was detected in 18 of the 60 $(30 \%)$ hipO $^{+}$samples, five VAGs were detected in 32 $(53.3 \%)$ samples, four VAGs were detected in seven (11.7\%)

Table 4. Molecular detection of Campylobacter spp. and C. jejuni VAGs in DNA samples extracted directly from the 366 stool samples

\begin{tabular}{|lc|}
\hline Gene detected (target) & $\begin{array}{c}\text { No. positive samples } \\
(\%)\end{array}$ \\
\hline $\begin{array}{l}\text { Campylobacter diagnosis } \\
\text { hipO (C. jejuni) }\end{array}$ \\
ask (C. coli) & $60(16.4)$ \\
C. jejuni VAGs $^{*}$ & $5(1.4)$ \\
ciaB & \\
dnaJ & $57(95.0)$ \\
racR & $52(86.7)$ \\
flaA & $59(98.3)$ \\
pldA & $48(80.0)$ \\
cdt $t$ B BC & $27(45.0)$ \\
pVir & $57(95.0)$ \\
\end{tabular}

${ }^{*}$ Tested on the 60 hipO-positive samples. samples and at least three VAGs (minimum detected) were detected in three $(5 \%)$ samples. In accordance with our findings, other studies regarding the prevalence of VAGs worldwide also found a very high proportion of these genes in different types of clinical and animal samples (Datta et al., 2003; Al-Mahmeed et al., 2006; Talukder et al., 2008; Ripabelli et al., 2010; Andrzejewska et al., 2011; Hamidian et al., 2011), especially ciaB (95-98\%) and the $c d t A B C$ operon (85-100\%).

We did not detect pVir among any of the hipO ${ }^{+}$samples, not even in samples from children whose guardians reported bloody diarrhoea (18/60), a scenario that has also been reported previously (Tracz et al., 2005). The absence of pVir may be due to lost plasmid material during the DNA extraction process; it may also be explained by the geographical characteristics of Campylobacter infection, as previously suggested (Louwen et al., 2006).

In cases of campylobacteriosis, the most studied C. jejuni virulence factor is CDT. Recently, a Danish group studied clinical samples from 30 patients with confirmed Campylobacter infections (Mortensen et al., 2011). As part of their analyses, they determined CDT activity in vitro and also sequenced the $c d t B$ portion of the $c d t$ operon gene, an interesting strategy that could be helpful in furthering our own studies, since we observed a difference in the prevalence of $c d t A B C$ genes between the present study (57/60, 95.0\%) and our previous case-control study (8/14, $57.1 \%$; da Silva Quetz et al., 2010).

Clinical symptoms of the disease did not appear to be associated with the detection of either C. jejuni or C.coli or with any particular combination of VAGs (Fisher's test, $P>0.05$ ). This differed from a previous report that found a higher rate of detection of two VAGs in one particular symptomatic group (Al-Mahmeed et al., 2006). Once again, this lack of association may be caused by geographical factors or individual circumstances relating to the Campylobacter infections. Further analysis will be necessary in order to investigate the proteins expressed during Campylobacter infection, since studies of the expressed protein products of enteric pathogens are crucial in determining the mechanisms by which they are able to cause disease and spread through the population. 


\section{Conclusions}

C. jejuni and its VAGs were detected in a high number of DNA samples extracted from faecal material of children who required medical care in two emergency rooms of Fortaleza, Brazil as a result of a diarrhoeal event. Using molecular tools, we were able to detect a considerable proportion of Campylobacter-positive faecal samples that had, at first, been declared as negative by culture-based methods. Further efforts will be directed to better determine the sensitivity of our protocol and to elucidate whether genetic factors or related expressed proteins play a role in Campylobacter pathogenesis.

\section{ACKNOWLEDGEMENTS}

This work was funded by the Program for Appropriate Technology in Health - PATH/USA (NIH1213-02-07494-Sub). The authors J. D. S. Q. and I. L. received scholarships from the Brazilian National Council for Scientific and Technological Development - CNPq (grant nos 140242/ 2009-0 and 152098/2008-9, respectively). We would like to thank Fabiana Nascimento from the Department of Ethics, Instituto de Biomedicina do Semi-Árido Brasileiro (IBISAB), for her invaluable help with this study. We are indebted to all the children from this study, and their guardians, for their participation.

\section{REFERENCES}

Al-Mahmeed, A., Senok, A. C., Ismaeel, A. Y., Bindayna, K. M., Tabbara, K. S. \& Botta, G. A. (2006). Clinical relevance of virulence genes in Campylobacter jejuni isolates in Bahrain. J Med Microbiol 55, 839-843.

Allos, B. M. (2001). Campylobacter jejuni infections: update on emerging issues and trends. Clin Infect Dis 32, 1201-1206.

Amieva, M. R. (2005). Important bacterial gastrointestinal pathogens in children: a pathogenesis perspective. Pediatr Clin North Am 52, 749-777, vi.

Andrzejewska, M., Klawe, J. J., Szczepańska, B. \& Spica, D. (2011). Occurrence of virulence genes among Campylobacter jejuni and Campylobacter coli isolates from domestic animals and children. Pol J Vet Sci 14, 207-211.

Bacon, D. J., Alm, R. A., Burr, D. H., Hu, L., Kopecko, D. J., Ewing, C. P., Trust, T. J. \& Guerry, P. (2000). Involvement of a plasmid in virulence of Campylobacter jejuni 81-176. Infect Immun 68, 43844390.

Bacon, D. J., Alm, R. A., Hu, L., Hickey, T. E., Ewing, C. P., Batchelor, R. A., Trust, T. J. \& Guerry, P. (2002). DNA sequence and mutational analyses of the pVir plasmid of Campylobacter jejuni 81-176. Infect Immun 70, 6242-6250.

Beltinger, J., del Buono, J., Skelly, M. M., Thornley, J., Spiller, R. C., Stack, W. A. \& Hawkey, C. J. (2008). Disruption of colonic barrier function and induction of mediator release by strains of Campylobacter jejuni that invade epithelial cells. World J Gastroenterol 14, 7345-7352.

Brandal, L. T., Lindstedt, B. A., Aas, L., Stavnes, T. L., Lassen, J. \& Kapperud, G. (2007). Octaplex PCR and fluorescence-based capillary electrophoresis for identification of human diarrheagenic Escherichia coli and Shigella spp. J Microbiol Methods 68, 331-341.

Brás, A. M., Chatterjee, S., Wren, B. W., Newell, D. G. \& Ketley, J. M. (1999). A novel Campylobacter jejuni two-component regulatory system important for temperature-dependent growth and colonization. J Bacteriol 181, 3298-3302. da Silva Quetz, J., Lima, I. F., Havt, A., de Carvalho, E. B., Lima, N. L., Soares, A. M., Mota, R. M., Guerrant, R. L. \& Lima, A. A. (2010). Campylobacter jejuni and Campylobacter coli in children from communities in Northeastern Brazil: molecular detection and relation to nutritional status. Diagn Microbiol Infect Dis 67, 220-227.

Dasti, J. I., Tareen, A. M., Lugert, R., Zautner, A. E. \& Gross, U. (2010). Campylobacter jejuni: a brief overview on pathogenicity-associated factors and disease-mediating mechanisms. Int J Med Microbiol 300, 205-211.

Datta, S., Niwa, H. \& Itoh, K. (2003). Prevalence of 11 pathogenic genes of Campylobacter jejuni by PCR in strains isolated from humans, poultry meat and broiler and bovine faeces. J Med Microbiol 52, 345-348.

Dediste, A., Vandenberg, O., Vlaes, L., Ebraert, A., Douat, N., Bahwere, P. \& Butzler, J. P. (2003). Evaluation of the ProSpecT microplate assay for detection of Campylobacter: a routine laboratory perspective. Clin Microbiol Infect 9, 1085-1090.

Fernández, H. (2011). [Campylobacter and campylobacteriosis: a view from South America]. Rev Peru Med Exp Salud Publica 28, 121-127 (in Spanish).

Fernández, H., Vera, F., Villanueva, M. P. \& García, A. (2008). Occurrence of Campylobacter species in healthy well-nourished and malnourished children. Braz J Microbiol 39, 56-58.

Fitzgerald, C., Helsel, L. O., Nicholson, M. A., Olsen, S. J., Swerdlow, D. L., Flahart, R., Sexton, J. \& Fields, P. I. (2001). Evaluation of methods for subtyping Campylobacter jejuni during an outbreak involving a food handler. J Clin Microbiol 39, 2386-2390.

Fouts, D. E., Mongodin, E. F., Mandrell, R. E., Miller, W. G., Rasko, D. A., Ravel, J., Brinkac, L. M., DeBoy, R. T., Parker, C. T. \& other authors (2005). Major structural differences and novel potential virulence mechanisms from the genomes of multiple Campylobacter species. PLoS Biol 3, e15.

Hamidian, M., Sanaei, M., Bolfion, M., Dabiri, H., Zali, M. R. \& Walther-Rasmussen, J. (2011). Prevalence of putative virulence markers in Campylobacter jejuni and Campylobacter coli isolated from hospitalized children, raw chicken, and raw beef in Tehran, Iran. Can J Microbiol 57, 143-148.

Inglis, G. D., Boras, V. F. \& Houde, A. (2011). Enteric campylobacteria and RNA viruses associated with healthy and diarrheic humans in the Chinook health region of Southwestern Alberta, Canada. J Clin Microbiol 49, 209-219.

Ivanova, K., Marina, M., Petrov, P. \& Kantardjiev, T. (2010). Campylobacteriosis and other bacterial gastrointestinal diseases in Sofia, Bulgaria for the period 1987-2008. Euro Surveill 15, 19474.

Jafari, F., Garcia-Gil, L. J., Salmanzadeh-Ahrabi, S., Shokrzadeh, L., Aslani, M. M., Pourhoseingholi, M. A., Derakhshan, F. \& Zali, M. R. (2009). Diagnosis and prevalence of enteropathogenic bacteria in children less than 5 years of age with acute diarrhea in Tehran children's hospitals. J Infect 58, 21-27.

Kaboré, H., Michel, P., Levallois, P., Déry, P., Payment, P. \& Lebel, G. (2010). A descriptive review of selected nonviral enteric illnesses reported in children in Quebec between 1999 and 2006. Can J Infect Dis Med Microbiol 21, e92-e98.

Konkel, M. E., Kim, B. J., Klena, J. D., Young, C. R. \& Ziprin, R. (1998), Characterization of the thermal stress response of Campylobacter jejuni. Infect Immun 66, 3666-3672.

Konkel, M. E., Kim, B. J., Rivera-Amill, V. \& Garvis, S. G. (1999). Bacterial secreted proteins are required for the internalization of Campylobacter jejuni into cultured mammalian cells. Mol Microbiol 32, 691-701.

Konkel, M. E., Klena, J. D., Rivera-Amill, V., Monteville, M. R., Biswas, D., Raphael, B. \& Mickelson, J. (2004). Secretion of virulence proteins from 
Campylobacter jejuni is dependent on a functional flagellar export apparatus. J Bacteriol 186, 3296-3303.

Lara-Tejero, M. \& Galán, J. E. (2001). CdtA, CdtB, and CdtC form a tripartite complex that is required for cytolethal distending toxin activity. Infect Immun 69, 4358-4365.

Louwen, R. P. L., van Belkum, A., Wagenaar, J. A., Doorduyn, Y., Achterberg, R. \& Endtz, H. P. (2006). Lack of association between the presence of the pVir plasmid and bloody diarrhea in Campylobacter jejuni enteritis. J Clin Microbiol 44, 1867-1868.

Maher, M., Finnegan, C., Collins, E., Ward, B., Carroll, C. \& Cormican, M. (2003). Evaluation of culture methods and a DNA probe-based PCR assay for detection of Campylobacter species in clinical specimens of feces. J Clin Microbiol 41, 2980-2986.

Mendes, E. N., Queiroz, D. M. M., Cisalpino, E. O., Peres, J. N., Penna, F. \& Figueiredo-Filho, P. P. (1987). Occurrence of Campylobacter jejuni in children with and without diarrhea in Belo Horizonte. Rev Microbiol Soc Bras Med 18, 25-30.

Moreno, A. C., Filho, A. F., Gomes, T. A., Ramos, S. T., Montemor, L. P., Tavares, V. C., Filho, L. S., Irino, K. \& Martinez, M. B. (2010). Etiology of childhood diarrhea in the northeast of Brazil: significant emergent diarrheal pathogens. Diagn Microbiol Infect Dis 66, 50-57.

Mortensen, N. P., Schiellerup, P., Boisen, N., Klein, B. M., Locht, H., Abuoun, M., Newell, D. \& Krogfelt, K. A. (2011). The role of Campylobacter jejuni cytolethal distending toxin in gastroenteritis: toxin detection, antibody production, and clinical outcome. APMIS 119, 626-634.

Podewils, L. J., Mintz, E. D., Nataro, J. P. \& Parashar, U. D. (2004). Acute, infectious diarrhea among children in developing countries. Semin Pediatr Infect Dis 15, 155-168.

Ripabelli, G., Tamburro, M., Minelli, F., Leone, A. \& Sammarco, M. L. (2010). Prevalence of virulence-associated genes and cytolethal distending toxin production in Campylobacter spp. isolated in Italy. Comp Immunol Microbiol Infect Dis 33, 355-364.

Sherman, P. M., Ossa, J. C. \& Wine, E. (2010). Bacterial infections: new and emerging enteric pathogens. Curr Opin Gastroenterol 26, 1-4.

Singh, H., Rathore, R. S., Singh, S. \& Cheema, P. S. (2011). Comparative analysis of cultural isolation and PCR based assay for detection of Campylobacter jejuni in food and faecal samples. Braz J Microbiol 42, 181-186.

Sinha, S., Prasad, K. N., Pradhan, S., Jain, D. \& Jha, S. (2004). Detection of preceding Campylobacter jejuni infection by polymerase chain reaction in patients with Guillain-Barré syndrome. Trans $R$ Soc Trop Med Hyg 98, 342-346.

Soofi, S. B., Habib, M. A., von Seidlein, L., Khan, M. J., Muhammad, S., Bhutto, N., Khan, M. I., Rasool, S., Zafar, A. \& other authors (2011). A comparison of disease caused by Shigella and Campylobacter species: 24 months community based surveillance in 4 slums of Karachi, Pakistan. J Infect Public Health 4, 12-21.

Talukder, K. A., Aslam, M., Islam, Z., Azmi, I. J., Dutta, D. K., Hossain, S., Nur-E-Kamal, A., Nair, G. B., Cravioto, A. \& other authors (2008). Prevalence of virulence genes and cytolethal distending toxin production in Campylobacter jejuni isolates from diarrheal patients in Bangladesh. J Clin Microbiol 46, 1485-1488.

Tam, C. C., O'Brien, S. J., Adak, G. K., Meakins, S. M. \& Frost, J. A. (2003). Campylobacter coli - an important foodborne pathogen. J Infect 47, 28-32.

Tracz, D. M., Keelan, M., Ahmed-Bentley, J., Gibreel, A., Kowalewska-Grochowska, K. \& Taylor, D. E. (2005). pVir and bloody diarrhea in Campylobacter jejuni enteritis. Emerg Infect Dis 11, 838-843.

Vu Nguyen, T., Le Van, P., Le Huy, C., Nguyen Gia, K. \& Weintraub, A. (2006). Etiology and epidemiology of diarrhea in children in Hanoi, Vietnam. Int J Infect Dis 10, 298-308.

Wang, G., Clark, C. G. \& Rodgers, F. G. (2002). Detection in Escherichia coli of the genes encoding the major virulence factors, the genes defining the O157:H7 serotype, and components of the type 2 Shiga toxin family by multiplex PCR. J Clin Microbiol 40, 3613-3619.

Wang, S. C., Chang, L. Y., Hsueh, P. R., Lu, C. Y., Lee, P. I., Shao, P. L., Hsieh, Y. C., Yen, F. P., Lee, C. Y. \& Huang, L. M. (2008). Campylobacter enteritis in children in northern Taiwan - a 7-year experience. J Microbiol Immunol Infect 41, 408-413.

Wassenaar, T. M. (1997). Toxin production by Campylobacter spp. Clin Microbiol Rev 10, 466-476.

Weigl, B. H., Gerdes, J., Tarr, P., Yager, P., Dillman, L., Peck, R., Ranachandran, S., Lemba, M., Kokoris, M. \& other authors (2006). Fully integrated multiplexed lab-on-a-card assay for enteric pathogens. Proc SPIE 6112, 611202.

Yager, P., Edwards, T., Fu, E., Helton, K., Nelson, K., Tam, M. R. \& Weigl, B. H. (2006). Microfluidic diagnostic technologies for global public health. Nature 442, 412-418.

Yamasaki, S., Asakura, M., Tsukamoto, T., Faruque, S. M., Deb, R. \& Ramamurthy, T. (2006). Cytolethal distending toxin (CDT): genetic diversity, structure and role in diarrheal disease. Toxin Rev 25, 61-88.

Young, V. B. \& Schauer, D. B. (2000). Cytolethal distending toxin: a bacterial toxin which disrupts the eukaryotic cell cycle. Chem Res Toxicol 13, 936-939.

Ziprin, R. L., Young, C. R., Byrd, J. A., Stanker, L. H., Hume, M. E., Gray, S. A., Kim, B. J. \& Konkel, M. E. (2001). Role of Campylobacter jejuni potential virulence genes in cecal colonization. Avian Dis 45, 549-557. 